\title{
Cu-Doped-CdS/In-Doped-CdS Cosensitized Quantum Dot Solar Cells
}

\author{
Lin Li, Xiaoping Zou, Hongquan Zhou, and Gongqing Teng \\ Research Center for Sensor Technology, Beijing Key Laboratory for Sensor, Ministry of Education Key Laboratory for \\ Modern Measurement and Control Technology, School of Applied Sciences, Beijing Information Science and Technology University, \\ Jianxiangqiao Campus, Beijing 100101, China
}

Correspondence should be addressed to Xiaoping Zou; xpzou2005@gmail.com

Received 18 January 2014; Accepted 19 February 2014; Published 27 March 2014

Academic Editor: Xitian Zhang

Copyright (C) 2014 Lin Li et al. This is an open access article distributed under the Creative Commons Attribution License, which permits unrestricted use, distribution, and reproduction in any medium, provided the original work is properly cited.

$\mathrm{Cu}$-doped-CdS and In-doped-CdS cosensitized (Cu-doped-CdS/In-doped-CdS) quantum dot solar cells (QDSCs) are introduced here. Different cosensitized sequences, doping ratios, and the thickness (SILAR cycles) of Cu-doped-CdS and In-doped-CdS are discussed. Compared with undoped CdS QDSCs, the short circuit current density, UV-Vis absorption spectra, IPCE (monochromatic incident photon-to-electron conversion), open circuit voltage, and so on are all improved. The photoelectric conversion efficiency has obviously improved from $0.71 \%$ to $1.28 \%$.

\section{Introduction}

Recently, introducing dopants to modify the properties of semiconductor nanocrystals was applied to improve the power conversion efficiency of QDSCs. Among so many quantum dot materials, CdS is an important II-VI compound semiconductor and its band width is $2.42 \mathrm{eV}$ at room temperature [1]. CdS has good optical properties in the visible light region. For the conduction, band energy level of $\mathrm{CdS}$ is above the conduction band of $\mathrm{TiO}_{2}$ and it is good for generation and delivery of electrons. CdS also has large extinction coefficient and photochemical stability. Moreover, we can control the size of CdS quantum dots to obtain wide absorbed spectrum [2-9]. Doping optically active transition metal ions was possible to modify the electronic and photophysical properties of QDs. For example, Lee and his coworkers prepared a cosensitized $\mathrm{TiO}_{2}$ electrode by CdSe and Mg-doped$\mathrm{CdSe}$ quantum dots (QDs) to broad spectrum in visible region. The power conversion efficiency of the cosensitized QDs photoelectrochemical solar cells (PECs) showed 1.03\%, which was higher than that of individual QDs-sensitized PECs. The incident-photon-to-current conversion efficiency of the cosensitized PECs showed absorption peaks at 541 and $578 \mathrm{~nm}$ corresponding to the two QDs and displayed a broad spectral response over the entire visible spectrum in the 500-600 nm wavelength domains [10]. Also, Santra and Kamat employed $\mathrm{Mn}^{2+}$ doping of CdS and they have now succeeded in significantly improving QDSC performance. QDSC constructed with Mn-doped-CdS/CdSe deposited on mesoscopic $\mathrm{TiO}_{2}$ film as photoanode, $\mathrm{Cu}_{2} \mathrm{~S} /$ graphene oxide composite electrode, and sulfide/polysulfide electrolyte deliver power conversion efficiency of 5.4\% [11]. They both applied metal ions modifying semiconductor quantum dot to get high $J_{\mathrm{sc}}, V_{\mathrm{oc}}$, and absorption peaks. However, the majority of doping was limited to single doping.

In this paper, we double doped the quantum dot sensitizer, introduced two levels [12], and doped the CdS quantum dot with $\mathrm{Cu}$, In. Compared with undoped CdS QDSCs, the short circuit current density, UV-Vis absorption spectra, IPCE (monochromatic incident photon-to-electron conversion), open circuit voltage, and so on are all improved. The photoelectric conversion efficiency has obviously improved from $0.71 \%$ to $1.28 \%$. Compared with single doping CdS QDSCs, the short circuit current density also improved.

\section{Materials and Methods}

2.1. $\mathrm{TiO}_{2}$ Films. $\mathrm{TiO}_{2}$ thin films were prepared on FTO conductive glass by screen printing method and then annealed 


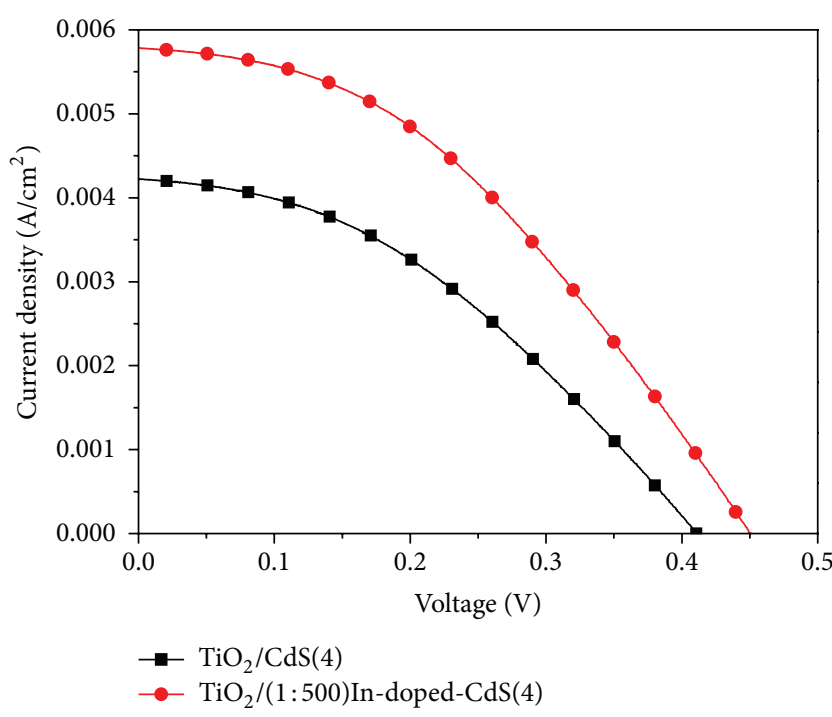

(a)

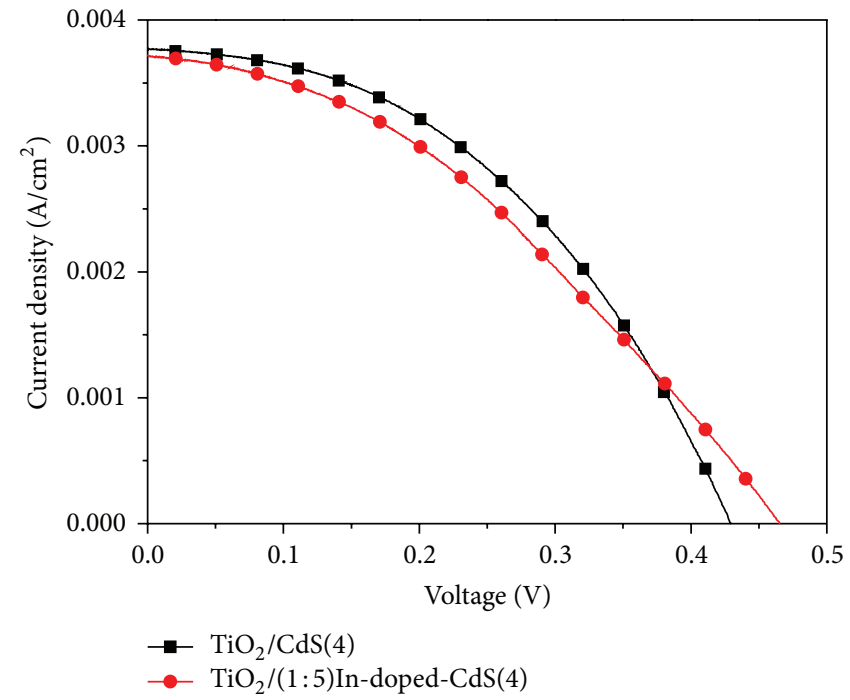

(b)

FIgure 1: (a) $J-V$ curves of undoped CdS QDSCs and Cu-doped-CdS QDSCs. (b) $J-V$ curves of undoped CdS QDSCs and In-doped-CdS QDSCs.

for 30 minutes at $450^{\circ} \mathrm{C}$. The thickness of $\mathrm{TiO}_{2}$ film was about $7 \sim 8 \mu \mathrm{m}$ and the working area was $0.4 \times 0.4 \mathrm{~cm}^{2}$. Then $\mathrm{Cu}$, In had been doped in quantum dots by SILAR method (successive ionic layer adsorption method).

2.2. Preparation of Cosensitized $\mathrm{TiO}_{2}$ Electrode with $\mathrm{Cu}$ Doped-CdS and In-Doped-CdS Quantum Dots. First, $0.1 \mathrm{M}$ $\mathrm{Cd}\left(\mathrm{NO}_{3}\right)_{2}$ ethanol solution was prepared with the $\mathrm{Cu}$ source $\left(\mathrm{CuCl}_{2}\right)$ added into the $\mathrm{Cd}\left(\mathrm{NO}_{3}\right)_{2}$ ethanol solution, forming a precursor solution of cation. $0.1 \mathrm{M} \mathrm{Na}_{2} \mathrm{~S}$ methanol solution was prepared as the precursor solution of anionic $\mathrm{S}^{2-}$. To obtain $\mathrm{Cu}$-doped-CdS quantum dots, the $\mathrm{TiO}_{2}$ photoanode was immersed into $\mathrm{Cd}\left(\mathrm{NO}_{3}\right)_{2}$ and $\mathrm{CuCl}_{2}$ hybrid ethanol solution for $5 \mathrm{~min}$, cleaned with alcohol and dried with nitrogen, and then immersed it into $\mathrm{Na}_{2} \mathrm{~S}$ methanol solution for $5 \mathrm{~min}$, cleaned with methanol and dried with nitrogen. After doing this, the $\mathrm{TiO}_{2}$ film was deposited by a layer of $\mathrm{Cu}$ doped-CdS quantum dots. Similarly, obtaining In-doped$\mathrm{CdS}$ quantum dots is by changing the $\mathrm{Cu}$ source with In source $\left(\mathrm{InCl}_{3}\right)$.

2.3. Counter Electrode. Two layers of the mixed solution of chloroplatinic acid and isopropanol are coated on the conductive surface of FTO glass. Then put the Pt electrode into the muffle furnace sintering at $450^{\circ} \mathrm{C}$ for $30 \mathrm{~min}$, cooled to $100^{\circ} \mathrm{C}$ and taken out, sealed with plastic wrap. The electrolyte of the solar cell is inorganic polysulfide electrolyte $(0.5 \mathrm{M}$ $\mathrm{Na}_{2} \mathrm{~S}, 2 \mathrm{M} \mathrm{S}$ and $0.2 \mathrm{M} \mathrm{KCl}$ ).

\section{Results and Discussions}

For explaining the properties of $\mathrm{Cu}$-doped-CdS and Indoped-CdS cosensitized QDSCs better, firstly, we discuss $\mathrm{Cu}$ doped-CdS QDSCs and In-doped-CdS QDSCs in our previous experiments briefly.
TABLE 1: The performance parameters of undoped CdS QDSCs and $\mathrm{Cu}$-doped-CdS QDSCs.

\begin{tabular}{lcccc}
\hline Samples & $J_{\text {sc }}\left(\mathrm{mA} / \mathrm{cm}^{2}\right)$ & $V_{\text {oc }}(\mathrm{mV})$ & $\mathrm{FF}$ & $\eta(\%)$ \\
\hline $\mathrm{TiO}_{2} / \mathrm{CdS}(4)$ & 4.28 & 412 & 0.39 & 0.67 \\
$\mathrm{TiO}_{2} / \mathrm{Cu}-\mathrm{CdS}(4)$ & 5.79 & 451 & 0.40 & 1.04 \\
\hline
\end{tabular}

TABLE 2: The performance parameters of undoped CdS QDSCs and In-doped-CdS QDSCs.

\begin{tabular}{lcccc}
\hline Samples & $J_{\text {sc }}\left(\mathrm{mA} / \mathrm{cm}^{2}\right)$ & $V_{\text {oc }}(\mathrm{mV})$ & $\mathrm{FF}$ & $\eta(\%)$ \\
\hline $\mathrm{TiO}_{2} / \mathrm{CdS}(4)$ & 3.77 & 431 & 0.44 & 0.71 \\
$\mathrm{TiO}_{2} / \mathrm{In}-\mathrm{CdS}(4)$ & 3.71 & 465 & 0.38 & 0.65 \\
\hline
\end{tabular}

Figure 1(a) was the $J-V$ curves of Cu-doped-CdS QDSCs. As we can see from it, compared with undoped CdS QDSCs, the short circuit current density of $\mathrm{Cu}$-doped-CdS QDSCs has a significant improvement. The specific parameters were in Table 1. The reasons for this are that by doping $\mathrm{Cu}$, it enhanced the conduction band of CdS QDs [12] and enhanced the energy level difference of $\mathrm{TiO}_{2}$ conduction band and $\mathrm{Cu}$-doped-CdS conduction band, so that it enhanced the injection power of excitons and then the short circuit current density of $\mathrm{Cu}$-doped-CdS QDSCs has a significant improvement. About In-doped-CdS QDSCs, the improvement was not so significant (Figure 1(b) and Table 2). The enhancement of CdS conduction band inspired us to introduce another higher conduction band to obtain better injection power. Next, we discuss $\mathrm{Cu}$-doped-CdS/In-dopedCdS QDSCs.

3.1. Different Cosensitized Sequences. Figure 2 describes the UV-Vis absorption spectra of undoped CdS quantum dot sensitized $\mathrm{TiO}_{2}$ photoanode and different cosensitized sequences of $\mathrm{Cu}$-doped-CdS and In-doped-CdS quantum dot sensitized 


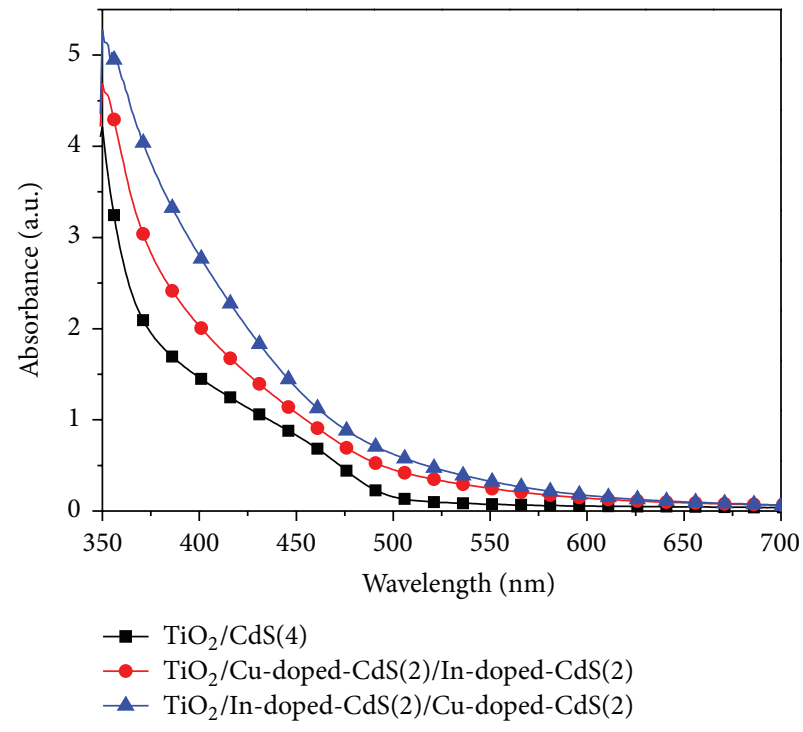

(a)

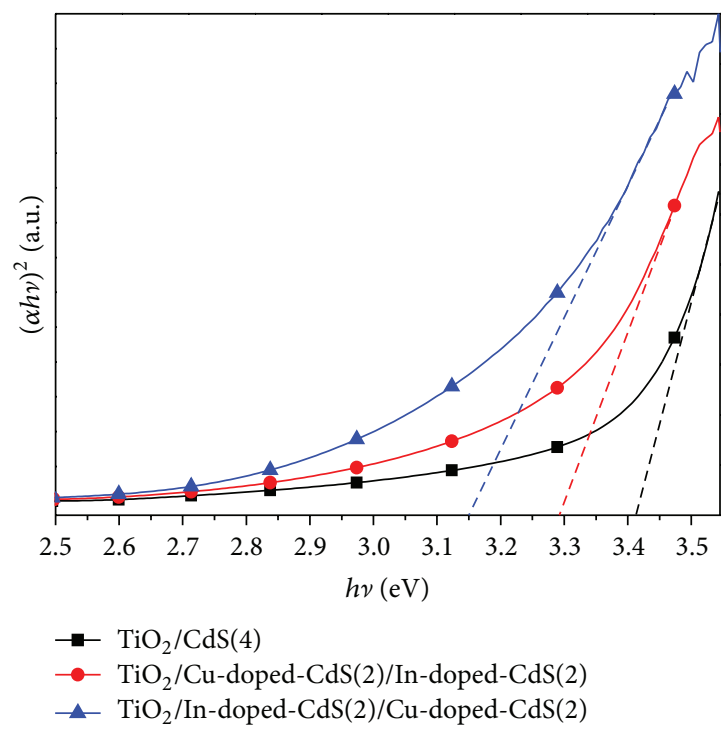

(b)

FIgURE 2: (a) The UV-Vis absorption spectra of three different conditions of CdS quantum dot sensitized $\mathrm{TiO}_{2}$ photo anode: undoped $\mathrm{CdS}$ quantum dots; $\mathrm{TiO}_{2} / \mathrm{Cu}$-doped-CdS/In-doped-CdS quantum dots; $\mathrm{TiO}_{2} / \mathrm{In}$-doped-CdS/Cu-doped-CdS quantum dots. (b) Absorption spectra of three samples obtained by $(\alpha h v)^{2}=h v-E g$.

$\mathrm{TiO}_{2}$ photo anode. The doping molar molar ratio of $\mathrm{Cu}$ is $1: 100$, doping molar ratio of In was $1: 5$, the SILAR cycles of $\mathrm{CdS}$ quantum dots was 4 , and the SILAR cycles of $\mathrm{Cu}$ doped CdS quantum dots and In doped CdS quantum dots were 2, respectively.

As for analysis from Figures 2(a) and 2(b), with $\mathrm{Cu}$, In doped, the absorption spectra of the samples regardless of $\mathrm{Cu}$-doped-CdS/In-doped-CdS (394 nm) or In-doped-CdS/ $\mathrm{Cu}$-doped-CdS $(377 \mathrm{~nm})$ began to move towards the long wavelength compared with undoped CdS $(364 \mathrm{~nm})$ sensitized $\mathrm{TiO}_{2}$ photoanode. And the band gaps of the samples decrease. The band gaps of undoped $\mathrm{CdS}$ sensitized $\mathrm{TiO}_{2}$ photoanode, $\mathrm{Cu}$-doped-CdS/In-doped-CdS sensitized $\mathrm{TiO}_{2}$ photoanode and In-doped-CdS/Cu-doped-CdS sensitized $\mathrm{TiO}_{2}$ photoanode are $3.41 \mathrm{eV}, 3.29 \mathrm{eV}$ and $3.15 \mathrm{eV}$, respectively. Among them, the absorption spectra of $\mathrm{TiO}_{2} / \mathrm{In}$ doped-CdS/Cu-doped-CdS samples red-shift compared with $\mathrm{TiO}_{2} / \mathrm{Cu}$-doped-CdS/In-doped-CdS samples and the exciton absorption peak of $\mathrm{TiO}_{2} / \mathrm{In}$-doped-CdS/Cu-doped-CdS sample is $394 \mathrm{~nm}$. Compared with undoped CdS quantum dots, the range of spectral response of double doped CdS quantum dots broaded, in other words the range of spectral response of double doped $\mathrm{CdS}$ sensitized $\mathrm{TiO}_{2}$ photoanode red-shift. When changing the cosensitized sequences, because the color of $\mathrm{Cu}$ was darker than the color of $\mathrm{In}$, the color of the prepared $\mathrm{TiO}_{2} / \mathrm{In}$-doped-CdS/Cu-dopedCdS photoanode films was also darker, so that the spectral response range of $\mathrm{TiO}_{2} / \mathrm{In}$-doped-CdS/Cu-doped-CdS was wider than the response spectrum range of the $\mathrm{TiO}_{2} / \mathrm{Cu}$ doped-CdS/In-doped-CdS.

Figure 3 describes the $J-V$ curves of undoped CdS QDSCs and Cu-doped-CdS, In-doped-CdS QDSCs cosensitized in different sequences. And the performance parameters of the solar cells were in Table 3.
TABLE 3: The performance parameters of solar cells in different conditions.

\begin{tabular}{lcccc}
\hline Samples & $J_{\mathrm{sc}}\left(\mathrm{mA} / \mathrm{cm}^{2}\right)$ & $V_{\mathrm{oc}}(\mathrm{mV})$ & $\mathrm{FF}$ & $\eta(\%)$ \\
\hline $\mathrm{TiO}_{2} / \mathrm{CdS}(4)$ & 3.77 & 431 & 0.44 & 0.71 \\
$\mathrm{TiO}_{2} / \mathrm{Cu}$-doped-CdS(2)/ & 6.49 & 498 & 0.35 & 1.13 \\
$\begin{array}{l}\mathrm{In} \text {-doped-CdS(2) } \\
\mathrm{TiO}_{2} / \mathrm{In} \text {-doped-CdS(2)/ }\end{array}$ & 6.12 & 442 & 0.38 & 1.03 \\
$\mathrm{Cu}$-doped-CdS(2) & & & & \\
\hline
\end{tabular}

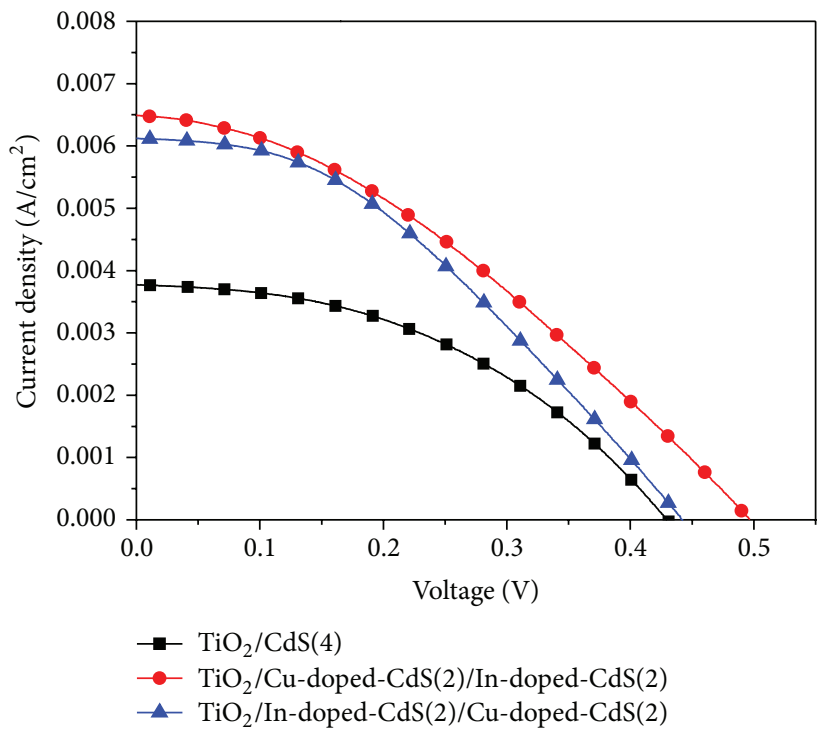

Figure 3: The $J-V$ curves of three samples assembled QDSCs.

As we can see in Figure 3 and Table 3, the photoelectric conversion efficiency of undoped CdS QDSCs (SILAR 4 times) was $0.71 \%$, By introduced In-doped-CdS quantum 

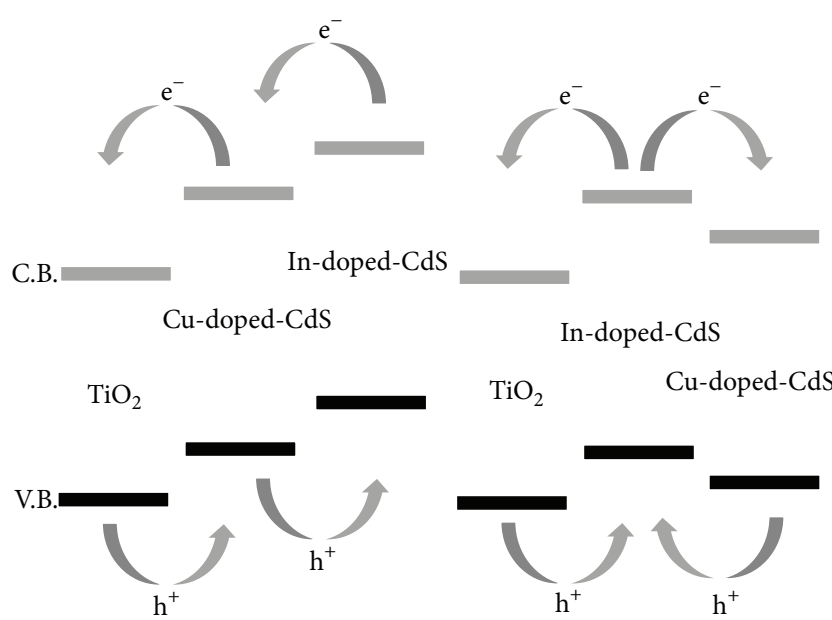

Figure 4: Energy level structure diagram of $\mathrm{TiO}_{2} / \mathrm{Cu}$-doped-CdS/ In-doped-CdS and $\mathrm{TiO}_{2} / \mathrm{In}$-doped-CdS/Cu-doped-CdS.

dots, the short circuit current density improved from $5.79 \mathrm{~mA} / \mathrm{cm}^{2}$ to $6.49 \mathrm{~mA} / \mathrm{cm}^{2}$ and the photoelectric conversion efficiency was also enhanced. Among them, the photoelectric conversion efficiency of $\mathrm{TiO}_{2} / \mathrm{Cu}$-doped-CdS/Indoped-CdS QDSCs was higher than $\mathrm{TiO}_{2} / \mathrm{In}$-doped-CdS/ $\mathrm{Cu}$-doped-CdS QDSCs, reaching 1.13\%, and the short circuit current density and the open circuit voltage were both the highest.

The reasons for the increase of the conversion efficiency of the solar cell can be comprehended from two aspects. (1) Compared with undoped quantum dots and $\mathrm{Cu}$-doped-CdS quantum dots, cosensitization of double doped CdS quantum dots can better increase the range and intensity of the absorption spectrum of the solar cell, improve the utilization rate of the incident light, improve the rate of capture of the photons, and increase the photocurrent density and the open circuit voltage, and double doped CdS electrode had lower dark current which was benefited for delivery of the electrons, inhibited for recombination of the electrons, thus ultimately improving photoelectric conversion efficiency of the solar cell. (2) $\mathrm{TiO}_{2} / \mathrm{Cu}$-doped-CdS/In-doped-CdS system can form a ladder band structure, as shown in Figure 4 . The conduction band and valence band position of the three materials increased in the sequence of $\mathrm{TiO}_{2}<\mathrm{Cu}$-dopedCdS < In-doped-CdS. The ladder structure was in favor of electron delivery and collection, reduced the recombination of electrons, and increased $J_{\mathrm{sc}}$ and $V_{\mathrm{oc}}$, and the photoelectric conversion efficiency of the solar cell increased. For $\mathrm{TiO}_{2} / \mathrm{In}$ doped-CdS/Cu-doped-CdS system, because it did not match the level structure, it introduces defects and impurities by doping, which led to the decrease of photoelectric conversion efficiency.

3.2. Doping Ratios and the Thickness (SILAR Cycles). Figures 5(a) and 5(b) have shown the physical graphs of $\mathrm{Cu}$-doped$\mathrm{CdS} / \mathrm{In}$-doped-CdS quantum dot sensitized $\mathrm{TiO}_{2}$ photoanodes by SILAR 4 cycles ((a) Cu-doped-CdS(2), In-doped$\mathrm{CdS}(2)$ ) and 8 cycles ((b) Cu-doped-CdS(4), In-dopedCdS(4)). As can be seen from the graph, with SILAR cycles
TABLE 4: The performance parameters of different SILAR cycles quantum dot sensed solar cells.

\begin{tabular}{|c|c|c|c|c|}
\hline Samples & $J_{\mathrm{sc}}\left(\mathrm{mA} / \mathrm{cm}^{2}\right)$ & $V_{\mathrm{oc}}(\mathrm{mV})$ & $\mathrm{FF}$ & $\eta(\%)$ \\
\hline $\begin{array}{l}\mathrm{TiO}_{2} / \mathrm{Cu} \text {-doped-CdS(1)/ } \\
\text { In-doped-CdS(1) }\end{array}$ & 1.85 & 430 & 0.48 & 0.38 \\
\hline $\begin{array}{l}\mathrm{TiO}_{2} / \mathrm{Cu} \text {-doped-CdS(2)/ } \\
\text { In-doped-CdS(2) }\end{array}$ & 4.36 & 462 & 0.35 & 0.71 \\
\hline $\begin{array}{l}\mathrm{TiO}_{2} / \mathrm{Cu} \text {-doped-CdS(3)/ } \\
\text { In-doped-CdS(3) }\end{array}$ & 6.08 & 436 & 0.31 & 0.81 \\
\hline $\begin{array}{l}\mathrm{TiO}_{2} / \mathrm{Cu} \text {-doped-CdS(4)/ } \\
\text { In-doped-CdS(4) }\end{array}$ & 6.98 & 418 & 0.34 & 0.99 \\
\hline $\begin{array}{l}\mathrm{TiO}_{2} / \mathrm{Cu} \text {-doped-CdS(5)/ } \\
\text { In-doped-CdS(5) }\end{array}$ & 6.18 & 405 & 0.31 & 0.77 \\
\hline
\end{tabular}

increasing, the color of the photoanodes was gradually deepened.

The UV-Vis absorption spectra were different for different SILAR cycles of Cu-doped-CdS/In-doped-CdS quantum dot sensitized $\mathrm{TiO}_{2}$ photoanode. Figure 6(a) has shown the UVVis absorption spectra of SILAR 4 cycles of $\mathrm{Cu}$-dopedCdS/In-doped-CdS quantum dot sensitized $\mathrm{TiO}_{2}$ photoanode. The doping ratio of $\mathrm{Cu}: \mathrm{Cd}$ was 1:100, doping ratio of In: Cd was 1:5, and the SILAR cycles were increased. Figure 6(b) has shown the absorption spectrum which was converted from Figure 6(a) by using formula $(\alpha h \nu)^{2}=h \nu-$ Eg.

By calculating the band gap of Figure 6(b), we found that the SILAR cycles of Cu-doped-CdS and In-dopedCdS gradually increased. Exciton absorption peak of the samples gradually moved towards the long wavelength and the band gap decreased. The reason was that with SILAR cycles increasing, the $\mathrm{Cu}$-doped-CdS quantum dots and Indoped-CdS quantum dots deposited on $\mathrm{TiO}_{2}$ photoanode gradually increased, which increased the light absorption of the samples and broadened the range of spectral response and the size of $\mathrm{Cu}$-doped-CdS/In-doped-CdS quantum dots also increased, thus finally leading to the samples redshift. Two kinds of doping ratios were discussed here that different SILAR cycles had different effects on $J-V$ of $\mathrm{Cu}$-dopedCdS/In-doped-CdS QDSCs.

The first kind was that doping ratio of $\mathrm{Cu}: \mathrm{Cd}$ was $1: 500$ and doping ratio of $\mathrm{In}: \mathrm{Cd}$ was $1: 5$. Figure 7 has shown $J-V$ curves of different SILAR cycles of Cu-doped-CdS/In-dopedCdS QDSCs. Table 4 has shown the performance parameters of different SILAR cycles quantum dot sensed solar cells.

As we can see from Figure 7(a) and Table 4, the short circuit current density and the conversion efficiency of the solar cell were increased with SILAR cycles increasing. When the SILAR cycles increased to 8 , the $J_{\mathrm{sc}}$ and $\eta$ of the solar cell reached the maximum value $\left(6.98 \mathrm{~mA} / \mathrm{cm}^{2}\right.$ and $\left.0.99 \%\right)$. If the SILAR cycles kept increasing, the parameters of the solar cells began to decline. The reason was that when the SILAR cycles was increased, a large number of $\mathrm{Cu}$-doped-CdS/In-doped$\mathrm{CdS}$ quantum dots were generated and deposited onto the $\mathrm{TiO}_{2}$ electrode. These factors made the delivery and collection of electrons more easy, so as to improve the $J_{\mathrm{sc}}$ and $\eta$. However, when the amount of QDs continued to increase, 


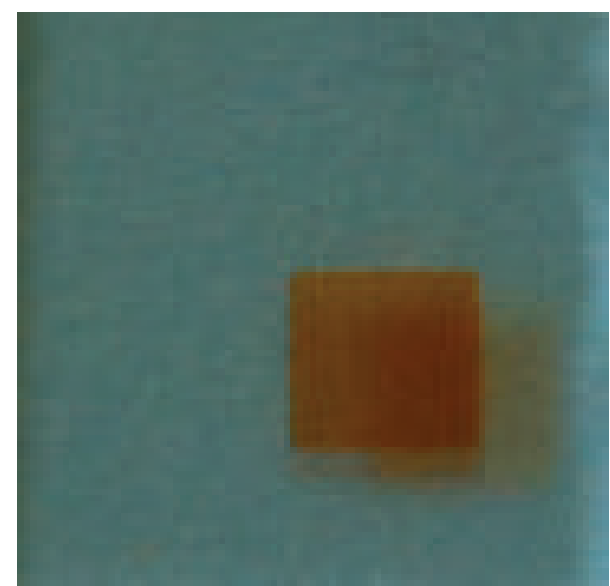

(a)

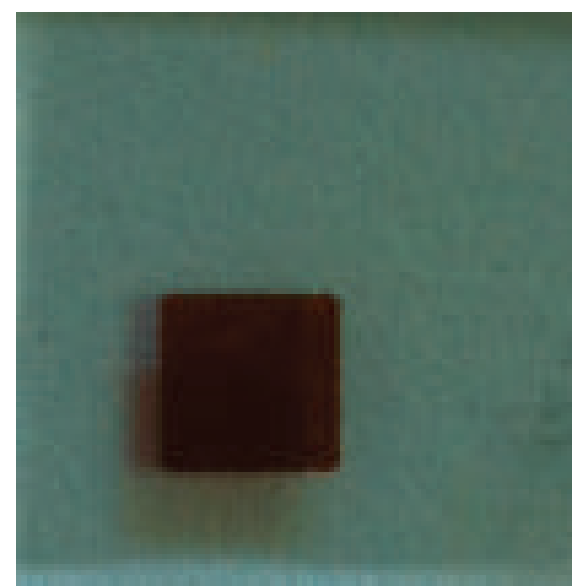

(b)

Figure 5: (a) Cu-doped-CdS(2)/In-doped-CdS(2) and (b) Cu-doped-CdS(4)/In-doped-CdS(4) of the quantum dot sensitized $\mathrm{TiO}_{2}$ photoanode physical graphs.

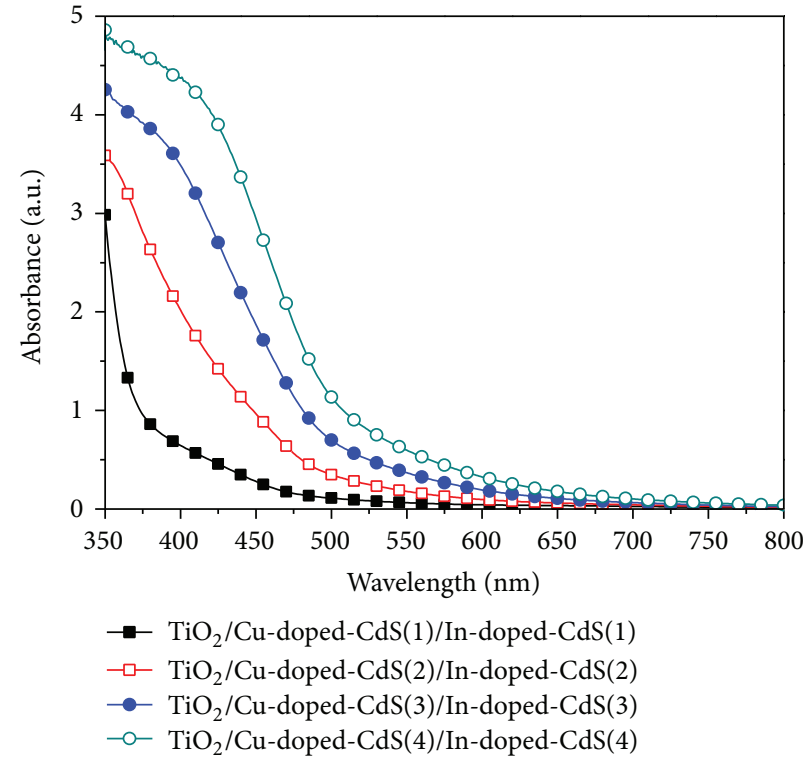

(a)

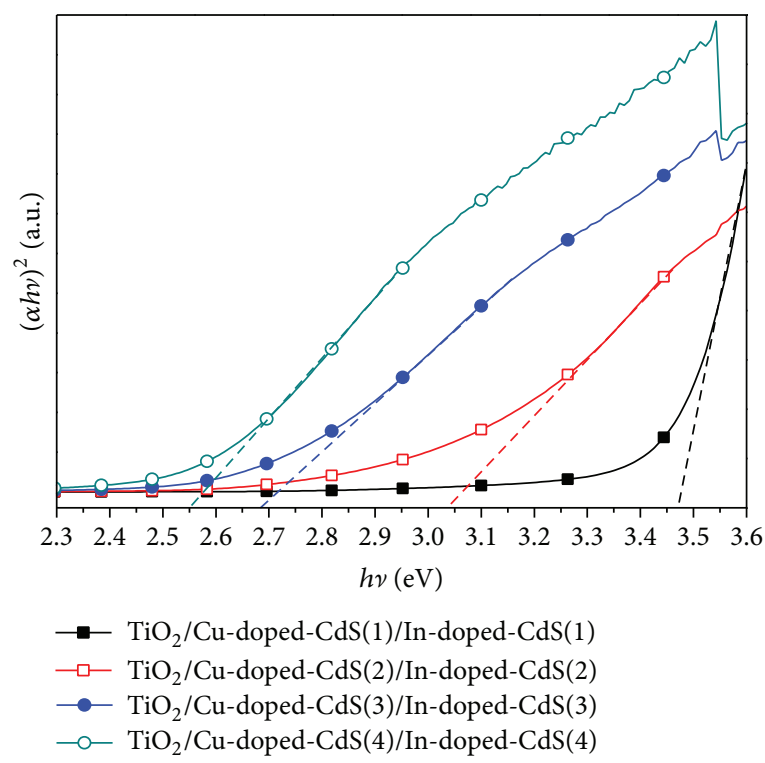

(b)

FIgURE 6: (a) UV-Vis absorption spectra of different SILAR cycles of Cu-doped-CdS/In-doped-CdS quantum dot sensitized TiO 2 photoanodes. (b) The absorption spectrum which was converted from (a) by using formula $(\alpha h \nu)^{2}=h \nu-E g$.

superfluous $\mathrm{Cu}$-doped-CdS/In-doped-CdS accumulated on the $\mathrm{TiO}_{2}$ surface of electrode. This result in a long distance delivery of the photoexcited electrons in different quantum dots. It prolonged the time of electron injection, increased the delivery resistance, and resulted in the decrease of photocurrent density. Moreover, superfluous quantum dots can also block the pores of $\mathrm{TiO}_{2}$, so it was bad for the electrolyte permeating in photoanode and it also hindered delivery of the electrons.

As we can see analysis from upside, the energy levels of $\mathrm{TiO}_{2} / \mathrm{Cu}$-doped-CdS(1)/In-doped-CdS(1) are not matching very well and we choose increasing $\mathrm{Cu}$ : $\mathrm{Cd}$ doping ratio as the Fermi level can go higher into the conduction band. So, we choose that the second kind of doping ratio of $\mathrm{Cu}: \mathrm{Cd}$ was $1: 100$ and the doping ratio of In was 1:5. Figure 7(b) has shown the $J-V$ curve of different SILAR cycles of $\mathrm{Cu}-$ doped-CdS/In-doped-CdS QDSCs. Table 5 has shown the performance parameters corresponding to Figure 7(b).

The regular patterns of four pictures were the same, but the photoelectric conversion efficiency of the latter was the highest with $1.28 \%$. So, from the four charts above, we can see that when the doping ratio of $\mathrm{Cu}: \mathrm{Cd}$ was $1: 100$, the doping ratio of In: Cd was 1:5, the SILAR cycles of $\mathrm{Cu}$-doped-CdS and In-doped-CdS were both 4 cycles, and the photoelectric conversion efficiency was the maximum.

At last, we discuss the curves of IPCE of different SILAR cycles of Cu-doped-CdS/In-doped-CdS QDSCs (Figure 8(a)). 


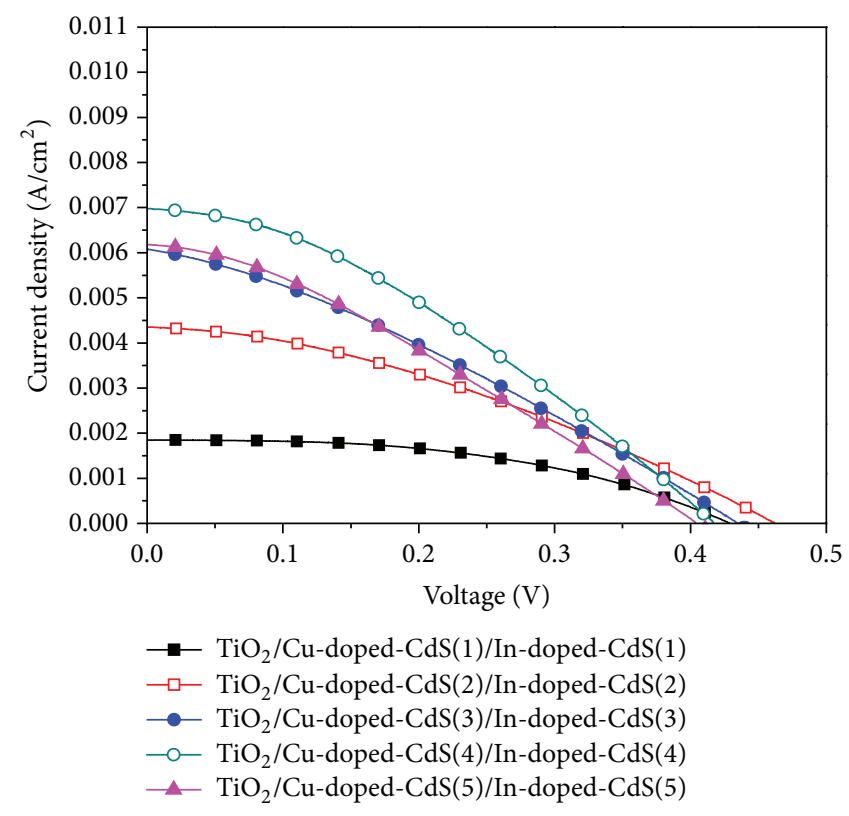

(a)

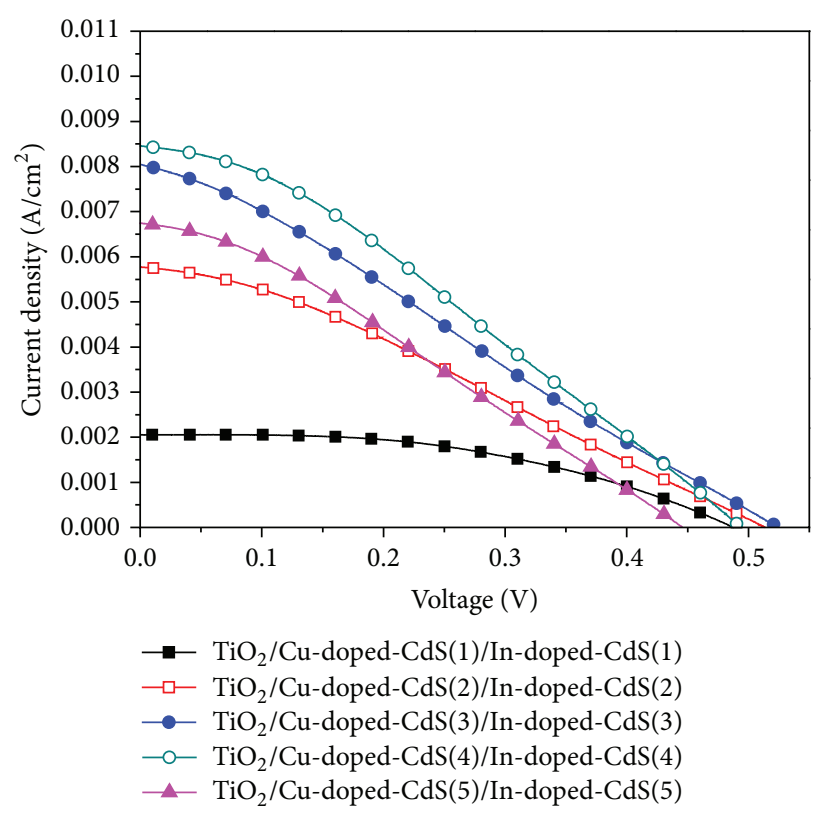

(b)

Figure 7: (a), (b) The $J$-V curves of different SILAR cycles of Cu-doped-CdS/In-doped-CdS QDSCs.

TABle 5: Performance parameters of different SILAR cycles of $\mathrm{Cu}-$ doped-CdS/In-doped-CdS QDSCs.

\begin{tabular}{|c|c|c|c|c|}
\hline Samples & $J_{\mathrm{sc}}\left(\mathrm{mA} / \mathrm{cm}^{2}\right)$ & $V_{\text {oc }}(\mathrm{mV})$ & $\mathrm{FF}$ & $\eta(\%)$ \\
\hline $\begin{array}{l}\mathrm{TiO}_{2} / \mathrm{Cu} \text {-doped-CdS(1)/ } \\
\text { In-doped-CdS(1) }\end{array}$ & 2.05 & 487 & 0.47 & 0.47 \\
\hline $\begin{array}{l}\mathrm{TiO}_{2} / \mathrm{Cu} \text {-doped-CdS(2)/ } \\
\text { In-doped-CdS(2) }\end{array}$ & 5.78 & 514 & 0.30 & 0.88 \\
\hline $\begin{array}{l}\mathrm{TiO}_{2} / \mathrm{Cu} \text {-doped-CdS(3)/ } \\
\text { In-doped-CdS(3) }\end{array}$ & 8.05 & 524 & 0.27 & 1.12 \\
\hline $\begin{array}{l}\mathrm{TiO}_{2} / \mathrm{Cu} \text {-doped-CdS(4)/ } \\
\text { In-doped-CdS(4) }\end{array}$ & 8.45 & 494 & 0.31 & 1.28 \\
\hline $\begin{array}{l}\mathrm{TiO}_{2} / \mathrm{Cu} \text {-doped-CdS(5)/ } \\
\text { In-doped-CdS(5) }\end{array}$ & 6.75 & 446 & 0.29 & 0.88 \\
\hline
\end{tabular}

As can be seen from the graph, with SILAR increasing, IPCE value and the spectral response range of the solar cell were greatly improved, and the initial absorption wavelength increased from $600 \mathrm{~nm}$ (SILAR 4 cycles) to $680 \mathrm{~nm}$ (SILAR 8 cycles). As we can see from the curve, with SILAR increasing, the starting absorption wavelength was obviously redshifted and this was consistent with the ultraviolet absorption spectrum and $J-V$ curves mentioned previously, and the conversion efficiency of the solar cell improved significantly.

The internal electron transfer complex properties of the $\mathrm{Cu}$-doped-CdS/In-doped-CdS quantum dot sensitized solar cell were important parameters. We tested EIS of the samples. Figure $8(\mathrm{~b})$ has shown the EIS spectrum of $\mathrm{Cu}$-doped-CdS/ In-doped-CdS QDSCs. Table 6 has shown the spectrum parameters corresponding to the EIS.

It was seen from Table 6 that, with the increase of SILAR cycles, the composite resistance $R_{\text {rec }}$ of photoanode and
TABLE 6: EIS parameters of different SILAR cycles Cu-dopedCdS/In-doped-CdS quantum dot sensitized solar cell.

\begin{tabular}{lccc}
\hline SILAR cycles & $R_{s}(\Omega)$ & $R_{\text {rec }}(\Omega)$ & $\mathrm{CPE}(\mu \mathrm{F})$ \\
\hline $\mathrm{TiO}_{2} / \mathrm{Cu}$-doped-CdS $(2) /$ & 41.17 & 6774 & 0.94183 \\
$\begin{array}{l}\text { In-doped-CdS }(2) \\
\mathrm{TiO}_{2} / \mathrm{Cu} \text {-doped-CdS }(4) /\end{array}$ & 114.10 & 4960 & 0.93803 \\
\begin{tabular}{l} 
In-doped-CdS $(4)$ \\
\hline
\end{tabular}
\end{tabular}

electrolyte was reduced from $6774 \Omega$ to $4960 \Omega$; in other words, the composite ability of the electrons was enhanced. The delivery probability of electrons between $\mathrm{Cu}$-doped-CdS quantum dots and In-doped-CdS quantum dots increases and this also resulted in an increased probability of electrons. But when SILAR cycles had been 8, the amount of $\mathrm{Cu}$-doped$\mathrm{CdS} /$ In-doped-CdS quantum dots had been larger than that of SILAR 4 cycles, so the photogenerated electrons increases and the short circuit current density increases.

\section{Conclusions}

In cosensitized $\mathrm{CdS}$ quantum dot sensitized solar cell system, for $\mathrm{TiO}_{2} / \mathrm{Cu}$-doped-CdS/In-doped-CdS QDSCs, double doping can increase the range and intensity of the absorption spectrum, improve the utilization rate of the incident light, increase the rate of photons capture, and increase the photocurrent density and open circuit voltage. It has low dark current and highly active electronic delivery, high inhibition of electronic recombination, which ultimately improves the photoelectric conversion efficiency of the solar cell. The conversion efficiency of $\mathrm{TiO}_{2} / \mathrm{Cu}$-doped-CdS/In-doped-CdS QDSCs is higher than $\mathrm{TiO}_{2} / \mathrm{In}$-doped-CdS/Cu-doped-CdS 


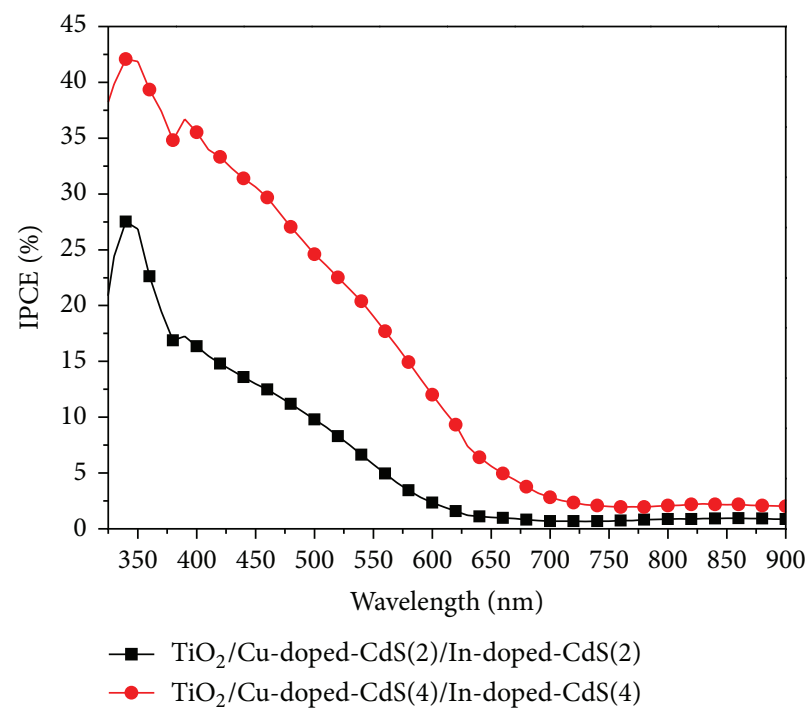

(a)

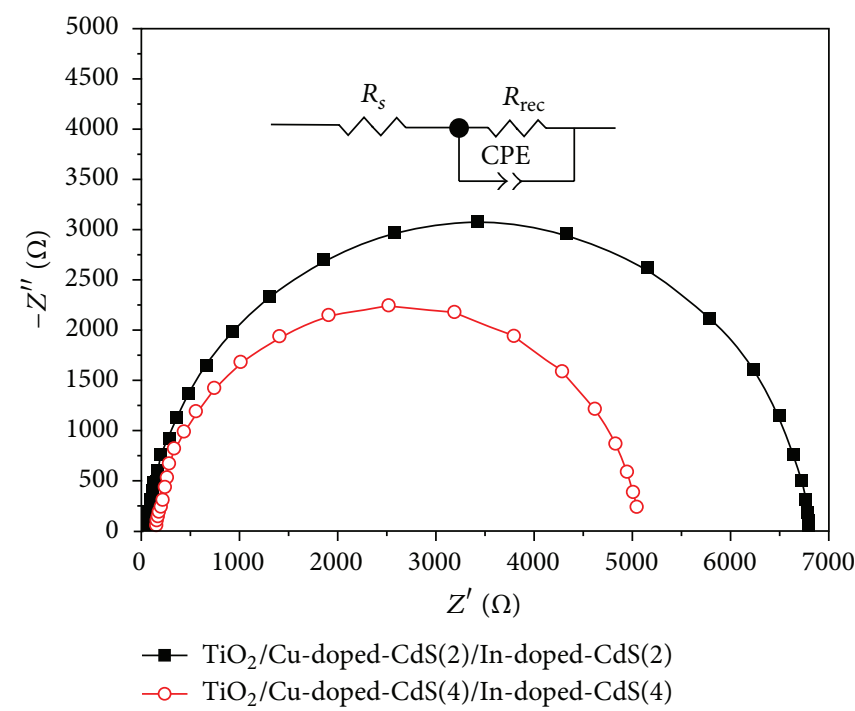

(b)

FIGURE 8: (a) Curves of IPCE of different SILAR cycles of Cu-doped-CdS/In-doped-CdS QDSCs. (b) EIS spectrum of different SILAR cycles of $\mathrm{Cu}$-doped-CdS/In-doped-CdS quantum dot sensitized solar cell.

QDSCs. The system $\mathrm{TiO}_{2} / \mathrm{Cu}$-doped-CdS/In-doped-CdS can form a ladder band structure and this kind of ladder type structures is in favor of electron delivery and collection, reduces the recombination center, and increases $J_{\mathrm{sc}}$ and $V_{\mathrm{oc}}$, so the photoelectric conversion efficiency of the solar cell is improved. With the ratio of $\mathrm{Cu}: \mathrm{Cd}(1: 100), \mathrm{In}: \mathrm{Cd}(1: 5)$, SILAR cycles (4) of the conversion efficiency of Cu-doped$\mathrm{CdS} / \mathrm{In}$-doped-CdS QDSCs reached the maximum value.

\section{Conflict of Interests}

The authors declare that there is no conflict of interests regarding the publication of this paper.

\section{Acknowledgments}

This work was partially supported by Key Project of Beijing Natural Science Foundation (3131001), Key Project of Natural Science Foundation of China (91233201), Key Project of Beijing Education Committee Science \& Technology Plan (KZ201211232040), State 863 Plan of MOST of PR China (2011AA050527), Beijing National Laboratory for Molecular Sciences (BNLMS2012-21), Key Laboratory for Semiconductor Materials Science of Institute of Semiconductors of CAS (KLSMS-1101), State Key Laboratory for New Ceramic and Fine Processing of Tsinghua University (KF1210), Key Laboratory for Renewable Energy and Gas Hydrate of Chinese Academy of Sciences (y207ka1001), Beijing Key Laboratory for Sensors of BISTU (KF20131077208), and Beijing Key Laboratory for Photoelectrical Measurement of BISTU (GDKF2013005).

\section{References}

[1] M. Grätzel, "Photoelectrochemical cells," Nature, vol. 414, no. 6861, pp. 338-344, 2001.

[2] Y.-L. Lee and C.-H. Chang, "Efficient polysulfide electrolyte for CdS quantum dot-sensitized solar cells," Journal of Power Sources, vol. 185, no. 1, pp. 584-588, 2008.

[3] Y. Jin-Nouchi, S.-I. Naya, and H. Tada, "Quantum-dot-sensitized solar cell using a photoanode prepared by in situ photodeposition of $\mathrm{CdS}$ on nanocrystalline $\mathrm{TiO}_{2}$ films," Journal of Physical Chemistry C, vol. 114, no. 39, pp. 16837-16842, 2010.

[4] H. Wang, Y. Bai, H. Zhang, Z. Zhang, J. Li, and L. Guo, "CdS quantum dots-sensitized $\mathrm{TiO}_{2}$ nanorod array on transparent conductive glass photoelectrodes," Journal of Physical Chemistry C, vol. 114, no. 39, pp. 16451-16455, 2010.

[5] M. Fujii, K. Nagasuna, M. Fujishima, T. Akita, and H. Tada, "Photodeposition of CdS quantum dots on $\mathrm{TiO}_{2}$ : preparation, characterization, and reaction mechanism," Journal of Physical Chemistry C, vol. 113, no. 38, pp. 16711-16716, 2009.

[6] R. S. Singh, V. K. Rnagari, and S. Sanagpalli, "Nano-structured $\mathrm{CdTe}, \mathrm{CdS}$ and $\mathrm{TiO}_{2}$ for thin film solar cell applications ," Solar Energy Materials and Solar Cells, vol. 82, no. 1-2, pp. 315-333, 2004.

[7] S. Tiwari and S. Tiwari, "Development of CdS based stable thin film photo electrochemical solar cells," Solar Energy Materials and Solar Cells, vol. 90, no. 11, pp. 1621-1628, 2006.

[8] Y.-L. Lee, C.-F. Chi, and S.-Y. Liau, "CdS/CdSe co-sensitized $\mathrm{TiO}_{2}$ photoelectrode for efficient hydrogen generation in a photoelectrochemical cell," Chemistry of Materials, vol. 22, no. 3, pp. 922-927, 2010.

[9] B. Li, W. Cai, L. Feng et al., "The preparation and properties of CdS thin films in solar cell," Optoelectronic Technology, vol. 24, no. 2, pp. 84-88, 2004.

[10] W. Lee, W. C. Kwak, S. K. Min et al., "Spectral broadening in quantum dots-sensitized photoelectrochemical solar cells based 
on CdSe and Mg-doped CdSe nanocrystals," Electrochemistry Communications, vol. 10, no. 79, pp. 1699-1702, 2008.

[11] P. K. Santra and P. V. Kamat, "Mn-doped quantum dot sensitized solar cells: a strategy to boost efficiency over 5\%," Journal of the American Chemical Society, vol. 134, no. 5, pp. 2508-2511, 2012.

[12] M. Wei and Y. Li, "A method for improving the parameters of quantum dot sensitized solar cell: the people's Republic of China," 201010608155. 5, 2011. 

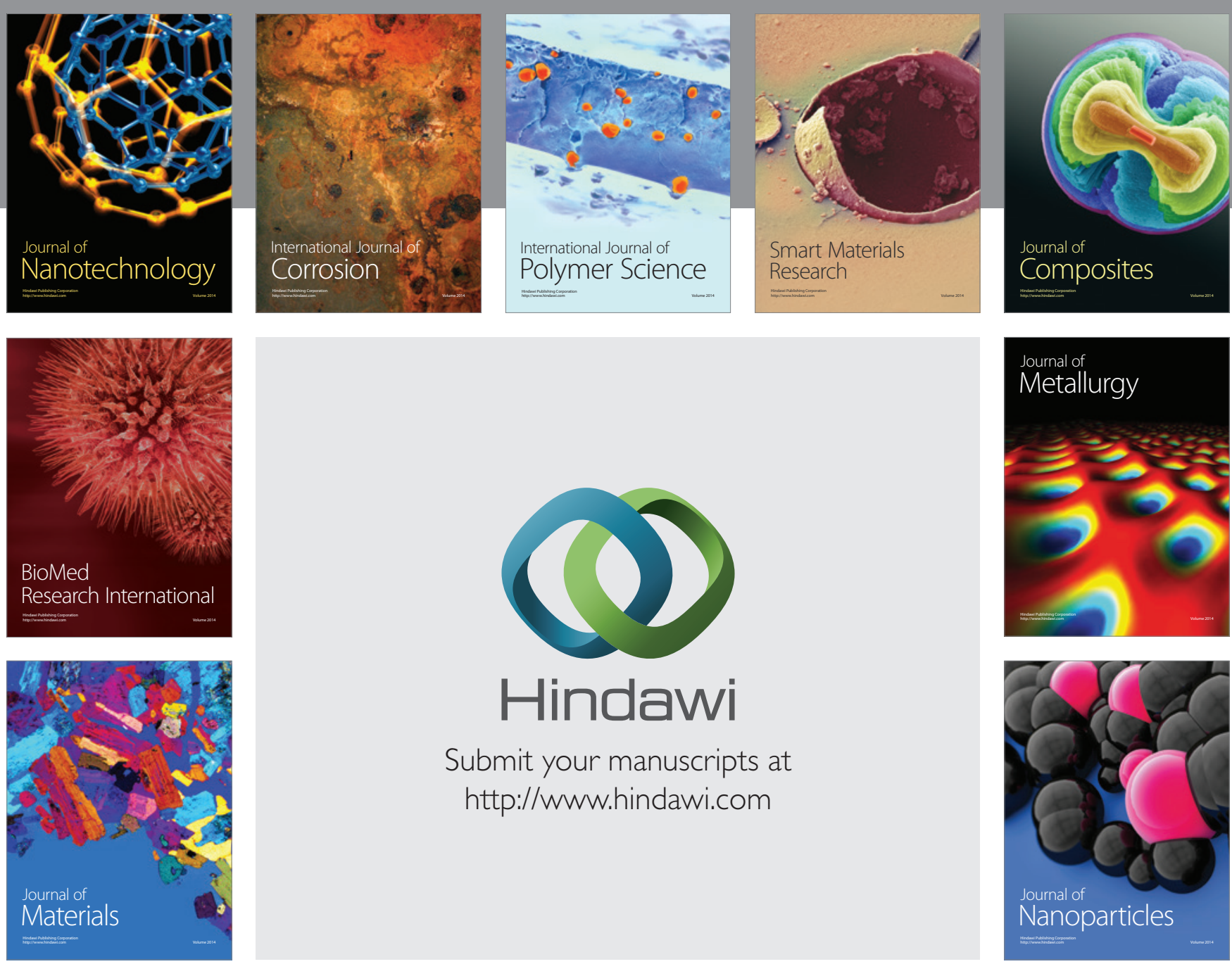

Submit your manuscripts at http://www.hindawi.com
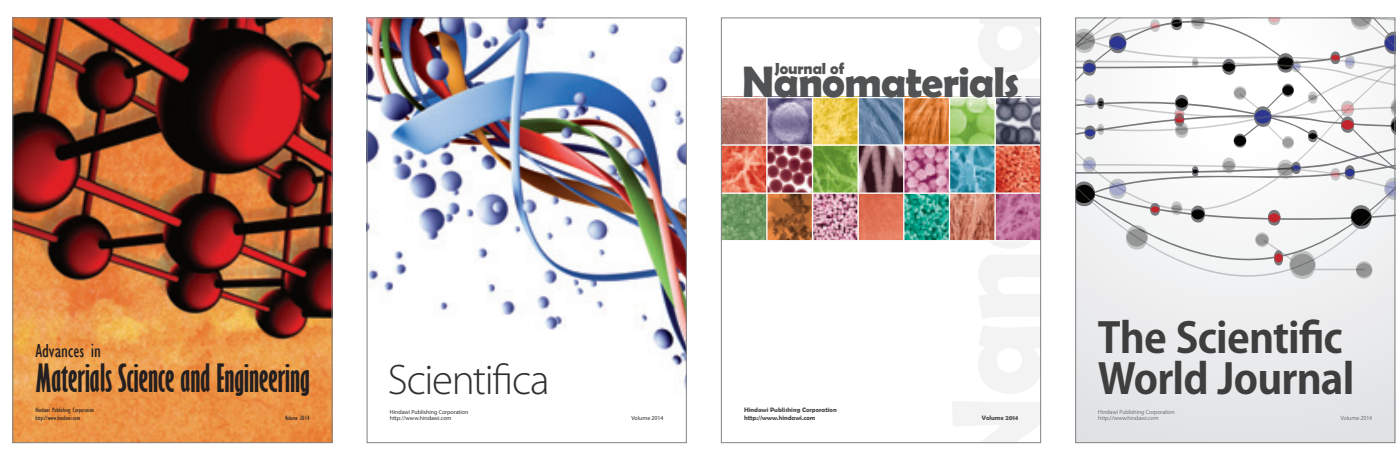

\section{The Scientific World Journal}
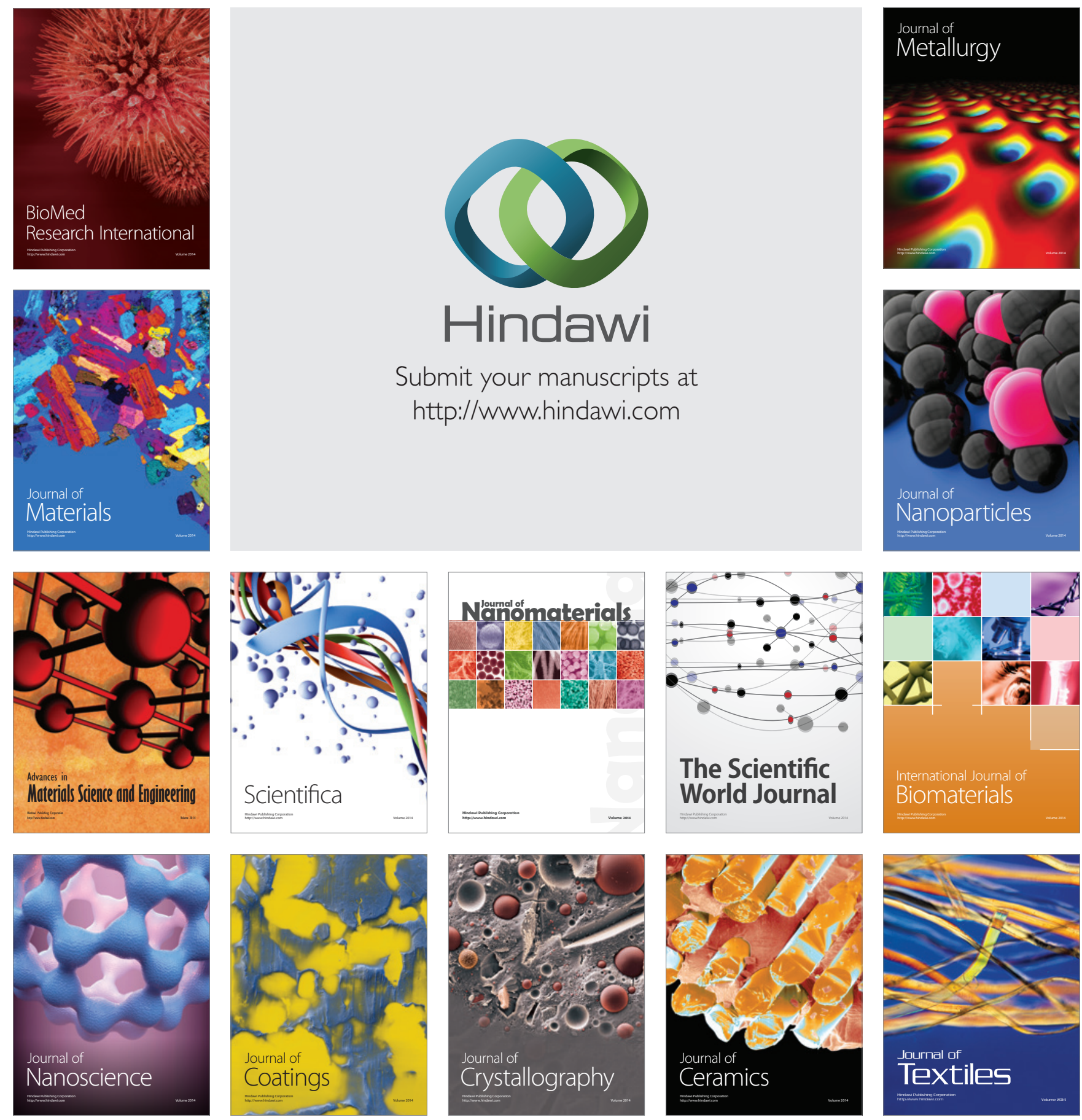